\begin{tabular}{|c|l|}
\hline Title & $\begin{array}{l}\text { Stable carbon isotopic compositions of total carbon, dicarboxylic acids and gly oxylic acid in the tropical Indian aerosols } \\
\text { : Implications for sources and photochemical processing of organic aerosols }\end{array}$ \\
\hline Author(s) & Pavuluri, Chandra Mouli; Kawamura, Kimitaka; Swaminathan, T.; T achibana, Eri \\
\hline Citation & $\begin{array}{l}\text { Journal of Geophysical Research, A tmospheres, 116, D18307 } \\
\text { https://doi.org/10.1029/2011D015617 }\end{array}$ \\
\hline Issue Date & 2011-09-29 \\
\hline Doc URL & http://hdl.handle.net/2115/48675 \\
\hline Rights & Copyright 2011 by the A merican Geophysical Union \\
\hline Type & article \\
\hline File Information & JGR116_D18307.pdf \\
\hline
\end{tabular}

Instructions for use 


\section{Stable carbon isotopic compositions of total carbon, dicarboxylic acids and glyoxylic acid in the tropical Indian aerosols: Implications for sources and photochemical processing of organic aerosols}

Chandra Mouli Pavuluri, ${ }^{1}$ Kimitaka Kawamura, ${ }^{1}$ T. Swaminathan, ${ }^{2}$ and Eri Tachibana ${ }^{1}$

Received 11 January 2011; revised 18 June 2011; accepted 28 June 2011; published 29 September 2011.

[1] The tropical Indian aerosols $\left(\mathrm{PM}_{10}\right)$ collected on day- and nighttime bases in winter and summer, 2007 from Chennai $\left(13.04^{\circ} \mathrm{N} ; 80.17^{\circ} \mathrm{E}\right)$ were studied for stable carbon isotopic compositions $\left(\delta^{13} \mathrm{C}\right)$ of total carbon (TC), individual dicarboxylic acids $\left(\mathrm{C}_{2}-\mathrm{C}_{9}\right)$ and glyoxylic acid $\left(\omega \mathrm{C}_{2}\right) \cdot \delta^{13} \mathrm{C}$ values of TC ranged from $-23.9 \%$ to $-25.9 \% 0(-25.0 \pm 0.6 \% ; \mathrm{n}=$ 49). Oxalic $\left(\mathrm{C}_{2}\right)\left(-17.1 \pm 2.5 \%\right.$ ), malonic $\left(\mathrm{C}_{3}\right)\left(-20.8 \pm 1.8 \%\right.$ ), succinic $\left(\mathrm{C}_{4}\right)(-22.5 \pm 1.5 \%$ o $)$ and adipic $\left(\mathrm{C}_{6}\right)(-20.6 \pm 4.1 \%)$ acids and $\omega \mathrm{C}_{2}$ acid $(-22.4 \pm 5.5 \%)$ were found to be more enriched with ${ }^{13} \mathrm{C}$ compared to TC. In contrast, suberic $\left(\mathrm{C}_{8}\right)(-29.4 \pm 1.8 \%$ ), phthalic $(\mathrm{Ph})(-30.1 \pm 3.5 \%)$ and azelaic $\left(\mathrm{C}_{9}\right)(-28.4 \pm 5.8 \%)$ acids showed smaller $\delta^{13} \mathrm{C}$ values than TC. Based on comparisons of $\delta^{13} \mathrm{C}$ values of TC in Chennai aerosols to those $(-24.7 \pm 2.2 \%$ ) found in unburned cow-dung samples collected from Chennai and isotopic signatures of the particles emitted from point sources, we found that biofuel/biomass burning are the major sources of carbonaceous aerosols in South and Southeast Asia. The decrease in $\delta^{13} \mathrm{C}$ values of $\mathrm{C}_{9}$ diacid by about $5 \%$ from winter to summer suggests that tropical plant emissions also significantly contribute to organic aerosol in this region. Significant increase in $\delta^{13} \mathrm{C}$ values from $\mathrm{C}_{4}$ to $\mathrm{C}_{2}$ diacids in Chennai aerosols could be attributed for their photochemical processing in the tropical atmosphere during long-range transport from source regions.

Citation: Pavuluri, C. M., K. Kawamura, T. Swaminathan, and E. Tachibana (2011), Stable carbon isotopic compositions of total carbon, dicarboxylic acids and glyoxylic acid in the tropical Indian aerosols: Implications for sources and photochemical processing of organic aerosols, J. Geophys. Res., 116, D18307, doi:10.1029/2011JD015617.

\section{Introduction}

[2] Carbonaceous aerosols that comprise elemental carbon (EC) and organic carbon (OC) have large impacts on human health [Baltensperger et al., 2008] and radiation budget in the atmosphere [Maria et al., 2004; Ramanathan et al., 2001]. Organic aerosols (OA), which represent a large fraction (20$90 \%$ ) of fine aerosols, are emitted from various primary sources and secondarily produced in the atmosphere by oxidation of volatile organic compounds (VOCs) followed by condensation on existing particles and/or nucleation. The pollutant emissions to the atmosphere are large in South and Southeast Asia due to growing economies, particularly in India [World Bank, 2000], and due to biomass burning including forest fires as well as widespread use of biofuels (dung cake, wood and agricultural waste) for cooking [Tata

\footnotetext{
${ }^{1}$ Institute of Low Temperature Science, Hokkaido University, Sapporo, Japan.

${ }^{2}$ Department of Chemical Engineering, Indian Institute of Technology Madras, Chennai, India.

Copyright 2011 by the American Geophysical Union. 0148-0227/11/2011JD015617
}

Energy Research Institute, 1997]. Heavily polluted atmospheres have been observed last decades in this region [Lelieveld et al., 2001], which cause a long-term dimming over the region that extends to the equatorial Indian Ocean [Ramanathan et al., 2001]. Recently, Pavuluri et al. [2010] found high concentrations (227-1030 $\mathrm{ng} \mathrm{m}^{-3}$ ) of dicarboxylic acids with high abundance of oxalic acid in the tropical Indian aerosols.

[3] However, the studies on origins of carbonaceous aerosols in South and Southeast Asia are sparse and ambiguous; Novakov et al. [2000] reported that fossil fuel combustion and biomass burning would contribute about $80 \%$ and 20\%, respectively. Recently, Venkataraman et al. [2005] estimated that contributions of fossil fuel combustion, open biomass burning and biofuel combustion to EC are $25 \%$, $33 \%$, and $42 \%$ whereas those to OC are $13 \%, 43 \%$, and $44 \%$, respectively. More recently, Gustafsson et al. [2009] found a much larger contribution of biomass burning to EC (48\%) and soot carbon (68\%). On the other hand, Stone et al. [2010] estimated a larger (54-84\%) contribution of non-combustion sources to OC, which were considered as secondary processes. Hence, it is highly important to better understand the major sources of atmospheric aerosols as well as their 


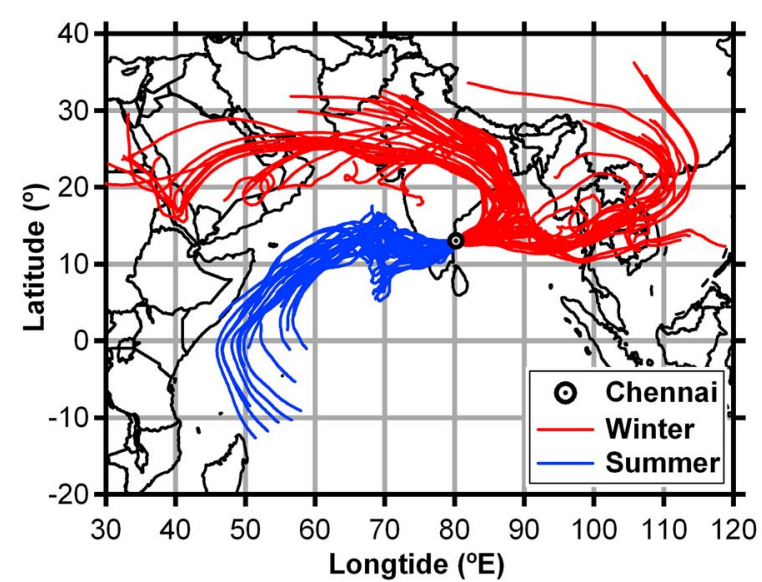

Figure 1. A map of South and Southeast Asia with sampling site, Chennai $\left(13.04^{\circ} \mathrm{N} ; 80.17^{\circ} \mathrm{E}\right)$, India together with plots of ten-day air mass trajectories arriving at an altitude of $500 \mathrm{~m}$ over Chennai in winter (January 23 to February 6 ) and summer (May 22-31), 2007.

photochemical processing during long-range transport in this region.

[4] Stable carbon isotopic compositions $\left(\delta^{13} \mathrm{C}\right)$ of total carbon (TC) and specific organic compounds are very useful for investigating sources and long-range atmospheric transport of organic aerosols [Cachier et al., 1985; Chesselet at al., 1981; Fang et al., 2002; Martinelli et al., 2002; Narukawa et al., 2008; Rudolph et al., 2003; Simoneit, 1997]. Compound specific stable carbon isotope analysis (CSCIA) of small hydrocarbons can provide highly valuable information on photochemical processing of individual compounds in the atmosphere, and contribution of effective mixing processes of the compounds during long-range transport [Rudolph et al., 2000, 2002, 2003; Saito et al., 2002]. Narukawa et al. [1999] demonstrated a significant contribution from flaming and/or smoldering combustion of $\mathrm{C}_{3}$ plants during largescale forest fires in Southeast Asia using $\delta^{13} \mathrm{C}$ values of aerosol carbon. Turekian et al. [2003] estimated the relative contributions of particulate carbon from marine and continental sources and identified the predominant marine contribution to oxalate at Bermuda on the basis of $\delta^{13} \mathrm{C}$.

[5] Recently, Kawamura and Watanabe [2004] developed a novel method for CSCIA of diacids and ketoacids using gas chromatography/isotope ratio mass spectrometry (GC/irMS). Since then, CSCIA of diacids has successfully been used to assess the extent of photochemical processing (aging) of aerosols during long-range atmospheric transport [Aggarwal and Kawamura, 2008; Wang and Kawamura, 2006]. Diacids and related polar compounds, which comprise a significant fraction of organic aerosols [Kawamura and Usukura, 1993], are mainly formed by secondary processes in the atmosphere [Kawamura et al., 1996; Satsumabayashi et al., 1990], although they can be generated from primary sources including fossil fuel combustion [Kawamura and Kaplan, 1987], biomass burning [Narukawa et al., 1999; Kundu et al., 2010] and meat cooking [Rogge et al., 1991]. In addition, photochemical oxidation of higher diacids is also an important process to produce lower diacids in the atmosphere [Kawamura et al., 2005].
[6] Here we report $\delta^{13} \mathrm{C}$ of $\mathrm{TC}$, diacids $\left(\mathrm{C}_{2}-\mathrm{C}_{9}\right)$ and glyoxylic acid $\left(\omega \mathrm{C}_{2}\right)$ in the tropical Indian aerosols $\left(\mathrm{PM}_{10}\right)$ collected from Chennai in winter and summer, 2007 and the $\delta^{13} \mathrm{C}$ values of TC measured in unburned cow-dung samples collected from Chennai. The origins of carbonaceous aerosols in South and Southeast Asia are identified based on $\delta^{13} \mathrm{C}$ values of the Chennai aerosols and their comparison to literature values together with the air mass trajectories. The results of $\delta^{13} \mathrm{C}$ of diacids and $\omega \mathrm{C}_{2}$ are discussed in terms of photochemical processing of aerosols during long-range transport in the tropical atmosphere. The temporal changes in $\delta^{13} \mathrm{C}$ values of diacids are also interpreted.

\section{Experimental}

\subsection{Aerosol and Cow-Dung Sampling}

[7] The tropical Indian aerosols $\left(\mathrm{PM}_{10}\right)$ were collected on day- (approximately 6:00-18:00 LT) and nighttime (18:006:00 LT) bases in winter (January 23 to February 6, $n=29$ ) and summer (May 22-31, $\mathrm{n}=20$ ) 2007 from a mega-city, Chennai $\left(13.04^{\circ} \mathrm{N} ; 80.17^{\circ} \mathrm{E}\right)$ located on the southeast coast of India (see Figure 1). Sampling was performed on the rooftop of the Mechanical Sciences building ( $\sim 18 \mathrm{~m}$ above the ground level), Indian Institute of Technology Madras (IITM), Chennai using a high volume air sampler (Envirotech APM $460 \mathrm{DX}$, India) and pre-combusted $\left(450^{\circ} \mathrm{C}, 4 \mathrm{~h}\right)$ quartz fiber filters (Pallflex 2500QAT-UP, $20 \times 25 \mathrm{~cm}$ ). The sample filter was placed in a pre-heated glass jar with a Teflon-lined screw cap and stored in darkness at $-20^{\circ} \mathrm{C}$ prior to analysis.

[8] Three cow-dung samples; (1) dung in cow barnyard, (2) commercially available dung cake that contained rice straw residue, and (3) dung pellets on roadside that were exposed to sun light and traffic emissions for several days were also collected from Chennai in May 2009. The samples were packed in aluminum foil and stored in a dark room at $-20^{\circ} \mathrm{C}$ prior to analysis.

\subsection{Determination of Stable Carbon Isotopic Ratios of Total Carbon}

[9] $\delta^{13} \mathrm{C}$ values of total carbon (TC) were determined using elemental analyzer coupled with isotope ratio mass spectrometry (EA/irMS) (Carlo Erba NA 1500 EA and Finnigan MAT Delta Plus) as reported elsewhere [Narukawa et al., 1999]. One disc (1.4 cm in diameter) of filter sample was placed in a tin cup, introduced into EA and then oxidized in a combustion column packed with $\mathrm{CuO}$ at $1020^{\circ} \mathrm{C}$. The derived gases $\left(\mathrm{CO}_{2}\right.$ and $\left.\mathrm{NO}_{x}\right)$ were introduced into the reduction column to reduce $\mathrm{NO}_{x}$ to $\mathrm{N}_{2}$ and then isolated on a gas chromatograph installed in the EA system. $\mathrm{CO}_{2}$ and $\mathrm{N}_{2}$ gases were transferred to EA/irMS via an interface (ConFlo II) for isotope ratio measurement. The $\delta^{13} \mathrm{C}$ values of TC relative to Pee Dee Belemnite (PDB) are calculated using the equation:

$$
\delta^{13} \mathrm{C}=\left[\left({ }^{13} \mathrm{C} /{ }^{12} \mathrm{C}\right)_{\text {sample }} /\left({ }^{13} \mathrm{C} /{ }^{12} \mathrm{C}\right)_{\text {standard }}-1\right] \times 1000 .
$$

[10] The analytical error based on replicate analysis was $0.1 \%$. Aerosol samples were not decarbonated prior to the measurements because we assume that Chennai aerosols may 
contain negligible amount of $\mathrm{CaCO}_{3}$ and its $\delta^{13} \mathrm{C}$ (around 0\%o) [Kawamura and Yasui, 2005; Wang et al., 2005] may not affect the $\delta^{13} \mathrm{C}$ of TC. In fact, $\mathrm{Ca}^{2+}$ concentrations were found to be low (range: $0.07-2.0 \mu \mathrm{g} \mathrm{m}^{-3}$; ave. $0.37 \mu \mathrm{g} \mathrm{m}^{-3}$ ) in these samples [Pavuluri et al., 2011] that further supports our assumption.

\subsection{Determination of Stable Carbon Isotopic Ratios of Dicarboxylic Acids and Glyoxylic Acid}

[11] $\delta^{13} \mathrm{C}$ values of diacids $\left(\mathrm{C}_{2}-\mathrm{C}_{9}\right)$ and glyoxylic acid $\left(\omega \mathrm{C}_{2}\right)$ relative to Pee Dee Belemnite (PDB) were measured using the method developed by Kawamura and Watanabe [2004]. Briefly, an aliquot of filter sample was extracted with Milli-Q water $(10 \mathrm{ml} \times 3)$ under ultrasonication for $10 \mathrm{~min}$. The extracts were concentrated to near dryness using a rotary evaporator under vacuum, and then reacted with $14 \% \mathrm{BF}_{3}$ in 1-butanol at $100^{\circ} \mathrm{C}$ to derive diacids and related compounds to dibutyl esters and/or dibutoxy acetals. The derivatized samples were extracted with $n$-hexane and then analyzed using a capillary gas chromatography (GC-FID; HP6890) and GC-mass spectrometry (GC-MS) system for their peak identification and concentrations [Kawamura, 1993; Kawamura and Ikushima, 1993; Pavuluri et al., 2010], prior to the stable carbon isotope analyses.

[12] An appropriate amount of internal standard $\left(\mathrm{n}-\mathrm{C}_{13}\right.$ alkane) was spiked to the derivatized fraction, and $\delta^{13} \mathrm{C}$ of the derivatives were determined using GC/irMS (HP 6890 $\mathrm{GC}$ and Finnigan-MAT Delta plus). $\delta^{13} \mathrm{C}$ of free diacids and $\omega \mathrm{C}_{2}$ in the sample were then calculated based on a mass balance equation using the measured $\delta^{13} \mathrm{C}$ of the derivatives and the derivatizing agent. The isotopic fractionation during derivatization step has been reported to be small $(<0.71 \%)$ based on the comparison of theoretical $\delta^{13} \mathrm{C}$ values of authentic diacid samples measured by EA/irMS and those of calculated $\delta^{13} \mathrm{C}$ values [Kawamura and Watanabe, 2004]. Each sample was analyzed in duplicate and the mean $\delta^{13} \mathrm{C}$ is reported. Difference in $\delta^{13} \mathrm{C}$ of free acids in duplicate analyses was generally below $1 \%$. However, for minor species, the difference was some times up to $1.5 \%$ and occasionally over $2 \%$.

\subsection{Meteorology}

[13] During the sampling, the ambient temperature and relative humidity varied from $14.2^{\circ} \mathrm{C}$ to $34.9^{\circ} \mathrm{C}$ (ave. $23^{\circ} \mathrm{C}$ ) and $38 \%$ to $89 \%$ (ave. $68 \%$ ) in winter, whereas in summer their ranges were $28.3-41^{\circ} \mathrm{C}$ (ave. $32^{\circ} \mathrm{C}$ ) and $31-81 \%$ (ave. $60 \%$ ), respectively. Wind speed and wind direction showed clear diurnal variations in both winter and summer [Pavuluri et al., 2010] due to land/sea breeze circulation that occur at the Chennai coast [Srinivas et al., 2006, 2007]. No rainfall was observed during the campaigns.

\subsection{Air Mass Trajectories}

[14] Ten-day air mass trajectories arriving in Chennai at an altitude of $500 \mathrm{~m}$ for every $6 \mathrm{~h}$ were computed using the HYSPLIT model of the National Oceanic and Atmospheric Administration (http://www.ready.noaa.gov/ready/ open/hysplit4.html). The results showed three major transport pathways with different source regions during the campaigns (see Figure 1). In winter (23 January to 6 February), the air masses that arrived in Chennai originated from the Middle East, the Indian mainland and/or the Southeast Asia. In summer (22-31 May), the air masses originated from the Arabian Sea and/or the Indian Ocean passing over southern part of the Indian subcontinent.

\section{Results and Discussion}

\subsection{Stable Carbon Isotopic Composition $\left(\delta^{13} \mathrm{C}\right)$ of Total Carbon}

[15] Table 1 presents $\delta^{13} \mathrm{C}$ values of total carbon (TC), together with diacids $\left(\mathrm{C}_{2}-\mathrm{C}_{9}\right)$ and glyoxylic acid $\left(\omega \mathrm{C}_{2}\right)$, in the tropical Indian aerosols $\left(\mathrm{PM}_{10}\right)$ collected on day- and nighttime bases in winter and summer 2007. Their averages and $95 \%$ confidence interval for day- and nighttime in winter and summer are shown in Figure 2. $\delta^{13} \mathrm{C}$ values of TC ranged from $-25.9 \%$ to $-23.9 \%$ o $(-25.0 \pm 0.6 \%$; $n=49)$. The $\delta^{13} \mathrm{C}$ of TC in Chennai aerosols did not show any significant seasonal or diurnal variation (Table 1 and Figure 2) although the source regions of air masses are different from season to season (Figure 1). As the air masses that arrived in Chennai passed over the Bay of Bengal in winter and originated from the Arabian Sea and/or Indian Ocean in summer (Figure 1), it is important to estimate the relative contribution of marine sources to TC.

[16] The isotopic composition of marine and continental carbonaceous aerosols has been well studied [Chesselet et al., 1981; Cachier et al., 1985] and the representative $\delta^{13} \mathrm{C}$ values for marine and continental carbon are considered to be $-21 \%$ and about $-26 \%$, respectively [Narukawa et al., 2008; Turekian et al., 2003]. Here, we applied these $\delta^{13} \mathrm{C}$ values as end-members of marine and continental aerosols to calculate the relative contributions using the following equations:

$$
\begin{aligned}
\delta^{13} \mathrm{C}_{\text {aerosol }}= & f_{\text {marine }} \times \delta^{13} \mathrm{C}_{\text {marine }}+f_{\text {continental }} \times \delta^{13} \mathrm{C}_{\text {continental }} \\
& f_{\text {marine }}+f_{\text {continental }}=1
\end{aligned}
$$

where $f_{\text {marine }}$ and $f_{\text {continental }}$ are the fractions of marine and continental carbon, respectively, and $\delta^{13} \mathrm{C}_{\text {marine }}$ and $\delta^{13} \mathrm{C}_{\text {continental }}$ are the isotopic values for two end-members.

[17] The estimated contributions of marine carbon to Chennai aerosols were from $1 \%$ to $37 \%$ with an average of $19 \%$. Our estimate (19\%) for Chennai aerosols is lower than those reported for marine aerosols collected at Bermuda (38\%) [Turekian et al., 2003] and high-Arctic aerosols (45\%) [Narukawa et al., 2008] that were affected by continental (anthropogenic) and marine sources. Thus, the carbonaceous aerosols in Chennai may have mainly originated from continental sources; fossil fuel combustion, biofuel/biomass burning and/or terrestrial plant emissions.

\subsection{Comparison of $\delta^{13} \mathrm{C}$ Values of $\mathrm{TC}$ in Chennai Aerosols With Literature Values}

[18] Figure 3a compares the range and/or mean (including standard deviation) of $\delta^{13} \mathrm{C}$ values of TC in ambient aerosols collected from various locations, which are influenced by specific sources, together with those of Chennai aerosols. $\delta^{13} \mathrm{C}$ of the particles collected during controlled combustions of vegetation and unburned cow-dung (source substance) samples are also depicted in Figure $3 \mathrm{~b} . \delta^{13} \mathrm{C}$ values found in Chennai aerosols $(-25.0 \pm 0.6 \%)$ are comparable to those reported for urban locations such as Tokyo $(-25.0 \pm$ $0.8 \%$ ) and Mexico City $(-25.1 \%$ ) where fossil fuel (probably 
Table 1. Stable Carbon Isotopic Ratios $\left(\delta^{13} \mathrm{C} ; \%\right)$ of Total Carbon (TC), Dicarboxylic Acids and Glyoxylic Acid in the Tropical Indian Aerosols $\left(\mathrm{PM}_{10}\right)$ Collected on Day- and Nighttime Bases in Winter (January 23 to February 6) and Summer (May 22-31) 2007 From Chennai, India ${ }^{\mathrm{a}}$

\begin{tabular}{|c|c|c|c|c|c|c|c|c|c|}
\hline \multirow[b]{2}{*}{ Sample ID } & \multirow[b]{2}{*}{$\mathrm{TC}$} & \multicolumn{7}{|c|}{ Diacids } & \multirow[b]{2}{*}{$\begin{array}{c}\text { Glyoxylic Acic } \\
\left(\omega \mathrm{C}_{2}\right)\end{array}$} \\
\hline & & $\begin{array}{l}\text { Oxalic } \\
\left(\mathrm{C}_{2}\right)\end{array}$ & $\begin{array}{c}\text { Malonic } \\
\left(\mathrm{C}_{3}\right)\end{array}$ & $\begin{array}{l}\text { Succinic } \\
\left(\mathrm{C}_{4}\right)\end{array}$ & $\begin{array}{l}\text { Adipic } \\
\left(\mathrm{C}_{6}\right)\end{array}$ & $\begin{array}{c}\text { Suberic } \\
\left(\mathrm{C}_{8}\right)\end{array}$ & $\begin{array}{c}\text { Azelaic } \\
\left(\mathrm{C}_{9}\right)\end{array}$ & $\begin{array}{c}\text { Phthalic } \\
\text { (Ph) }\end{array}$ & \\
\hline \multicolumn{10}{|c|}{ Winter (January 23 to February 6, 2007) } \\
\hline IND091 & -24.1 & -15.3 & -18.8 & -20.4 & & & & -28.1 & -25.6 \\
\hline IND092 & -25.5 & -19.4 & -18.6 & -21.5 & & & -25.1 & -30.2 & -17.6 \\
\hline IND093 & -25.1 & -21.0 & -18.9 & -22.4 & & -26.9 & -27.5 & -32.6 & -30.3 \\
\hline IND096 & -25.1 & -15.3 & -24.2 & -24.8 & & & & & -11.2 \\
\hline IND097 & -24.6 & -18.6 & -20.2 & -22.0 & & -29.8 & & -30.2 & -24.6 \\
\hline IND098 & -24.8 & -19.8 & -20.3 & -22.5 & & & & -25.8 & -21.7 \\
\hline IND100 & -25.0 & -18.9 & -20.6 & -22.2 & & -31.0 & -20.1 & -32.4 & -28.2 \\
\hline IND101 & -25.1 & -19.6 & -22.2 & -25.3 & & -33.8 & -23.5 & -29.4 & -32.3 \\
\hline IND102 & -24.2 & -17.5 & -22.9 & -22.2 & & -29.5 & -30.1 & -30.8 & -19.5 \\
\hline IND103 & -24.4 & -17.4 & -19.7 & -22.6 & & & -30.1 & -30.9 & -27.6 \\
\hline IND104 & -25.0 & -19.5 & -21.4 & -22.8 & -21.7 & -28.6 & -30.6 & -34.6 & -23.7 \\
\hline IND105 & -24.0 & -16.8 & -17.8 & -22.9 & & -30.2 & -28.8 & -31.8 & -23.9 \\
\hline IND106 & -24.0 & -13.9 & -19.9 & -23.7 & & -29.2 & -27.1 & -32.0 & -28.8 \\
\hline IND108 & -24.2 & -15.2 & -18.6 & -22.6 & & -29.2 & -29.9 & -29.1 & -22.9 \\
\hline IND110 & -24.4 & -15.3 & -21.4 & -20.7 & & -29.4 & -34.2 & -29.7 & -18.6 \\
\hline IND111 & -24.0 & -15.7 & -18.8 & -20.5 & & -28.8 & -35.3 & -31.7 & -20.2 \\
\hline IND112 & -24.8 & -15.8 & -20.5 & -22.3 & & -28.0 & -20.6 & -33.8 & -18.2 \\
\hline IND113 & -25.5 & -14.8 & -19.9 & -22.6 & -16.9 & -27.7 & -18.0 & -26.2 & -14.6 \\
\hline IND116 & -25.3 & -19.6 & -20.7 & -23.3 & & -28.1 & -35.2 & -29.9 & -26.1 \\
\hline IND117 & -25.8 & -19.3 & -22.1 & -23.3 & & -31.0 & -21.8 & -40.7 & -33.6 \\
\hline IND120 & -25.8 & -17.2 & -19.2 & -23.3 & -17.7 & -28.1 & -30.8 & -31.1 & -19.6 \\
\hline IND121 & -25.4 & -20.7 & -22.1 & -23.3 & & & & -30.2 & -28.9 \\
\hline IND122 & -25.4 & -17.6 & -21.5 & -21.9 & -16.7 & -27.7 & -23.6 & -30.7 & -18.8 \\
\hline IND123 & -24.9 & -16.9 & -23.4 & -23.4 & & -29.9 & -20.0 & -22.0 & -23.3 \\
\hline IND124 & -25.4 & -12.4 & -22.5 & -22.8 & & -30.8 & -39.1 & -30.6 & -21.1 \\
\hline IND125 & -25.5 & -15.5 & -22.4 & -22.3 & -13.6 & -27.4 & -21.9 & -25.1 & -12.6 \\
\hline IND126 & -25.2 & -17.8 & -21.8 & -21.6 & -25.2 & -28.3 & -31.2 & -30.3 & -19.1 \\
\hline IND127 & -25.6 & -17.9 & -21.2 & -23.5 & -16.1 & -30.1 & -21.4 & -24.6 & -20.7 \\
\hline IND128 & -25.5 & -19.9 & -25.1 & -23.4 & -10.8 & -28.3 & -25.3 & -31.1 & -28.5 \\
\hline Ave. \pm CI & $-25.0 \pm 0.2$ & $-17.4 \pm 0.8$ & $-20.9 \pm 0.7$ & $-22.6 \pm 0.4$ & $-17.3 \pm 3.1$ & $-29.2 \pm 0.6$ & $-27.1 \pm 2.3$ & $-30.2 \pm 1.3$ & $-22.8 \pm 2.0$ \\
\hline \multicolumn{10}{|c|}{ Summer (May 22-31, 2007) } \\
\hline IND171 & -25.0 & -16.4 & -19.6 & -21.1 & -19.6 & -27.9 & -29.5 & -29.1 & -14.0 \\
\hline IND172 & -25.8 & -18.2 & -20.3 & -24.2 & -20.6 & & & & -22.1 \\
\hline IND174 & -25.0 & -19.3 & -20.5 & -22.2 & & -30.3 & -40.0 & -34.0 & -18.9 \\
\hline IND175 & -24.9 & -17.3 & -22.2 & -22.1 & -18.6 & & & & -20.0 \\
\hline IND176 & -25.1 & -11.0 & -15.5 & -21.3 & -24.9 & -24.5 & -26.8 & -23.7 & -13.2 \\
\hline IND177 & -25.0 & -14.5 & -21.0 & -20.9 & -19.6 & -31.9 & & & -29.3 \\
\hline IND178 & -23.9 & -15.8 & -20.6 & -19.6 & -22.6 & -27.0 & -30.2 & -28.7 & -23.8 \\
\hline IND179 & -25.1 & -15.0 & -21.1 & -21.3 & -19.2 & & & & -22.6 \\
\hline IND180 & -24.2 & -16.4 & -19.8 & -21.2 & -22.1 & -32.5 & -31.7 & -28.3 & -21.6 \\
\hline IND181 & -25.5 & -21.5 & -20.7 & -27.4 & & -31.2 & -36.9 & & -27.0 \\
\hline IND182 & -24.0 & -17.9 & -18.2 & -20.5 & -26.2 & -30.2 & & & -22.8 \\
\hline IND183 & -25.6 & -16.5 & -20.4 & -21.4 & -24.5 & & & & -25.8 \\
\hline IND184 & -24.5 & -18.6 & -21.5 & -21.9 & -18.8 & & & & -18.7 \\
\hline IND186 & -24.5 & -21.5 & -24.9 & -23.9 & & & -32.6 & & -26.0 \\
\hline IND187 & -24.8 & -19.4 & -21.2 & -23.7 & -18.3 & -29.8 & -29.7 & -34.4 & -8.5 \\
\hline IND188 & -25.1 & -15.8 & -20.6 & -24.0 & -27.5 & & & & -26.9 \\
\hline IND189 & -25.0 & -9.2 & -20.6 & -20.9 & -24.8 & & & & -19.2 \\
\hline IND190 & -25.6 & -17.2 & -19.5 & -22.4 & -22.3 & -30.1 & & -30.7 & -27.3 \\
\hline IND191 & -24.5 & -17.7 & -21.4 & -20.1 & -23.5 & -31.3 & & & -20.6 \\
\hline IND192 & -25.9 & -15.6 & -20.8 & -24.4 & -23.3 & & & & -29.4 \\
\hline Ave. \pm CI & $-25.0 \pm 0.2$ & $-16.7 \pm 1.3$ & $-20.5 \pm 0.8$ & $-22.2 \pm 0.8$ & $-22.1 \pm 1.4$ & $-29.7 \pm 1.4$ & $-32.2 \pm 3.0$ & $-29.8 \pm 2.7$ & $-21.9 \pm 2.4$ \\
\hline
\end{tabular}

${ }^{a}$ Ave. $=$ Average; $\mathrm{CI}=95 \%$ Confidence Interval.

petrol) combustion was expected [López-Veneroni, 2009; K. Kawamura, unpublished data, 2003]. In contrast, these values are higher than those of road tunnel aerosols from Canada $(-27.3 \%)$, but are comparable to those $(-25.5 \%$ ) reported over forest area (Ivory coast) and Amazon Basin, Brazil, where the $\mathrm{C}_{3}$ plant burning was expected as significant source [Martinelli et al., 2002], as well as the higher ends (range, $-27.5 \%$ to $-25.5 \%$ ) reported for Southeast
Asian aerosols collected during Indonesian forest fires (Figure $3 \mathrm{a}$ ). $\delta^{13} \mathrm{C}$ of Chennai aerosols are lower than those $(-20.9 \pm 0.8 \%$ ) reported from Piracicaba, Brazil, where the $\mathrm{C}_{4}$ plant burning was expected [Martinelli et al., 2002].

[19] The $\delta^{13} \mathrm{C}$ values of Chennai aerosols are comparable to those reported for the particles emitted from the burning of $\mathrm{C}_{3}$ plants $(-23.8 \%$ o to $-27.4 \%$ ), and unburned dung $(-25.7 \pm$ $0.4 \%$ ) from beef steer fed on silage made from perennial 


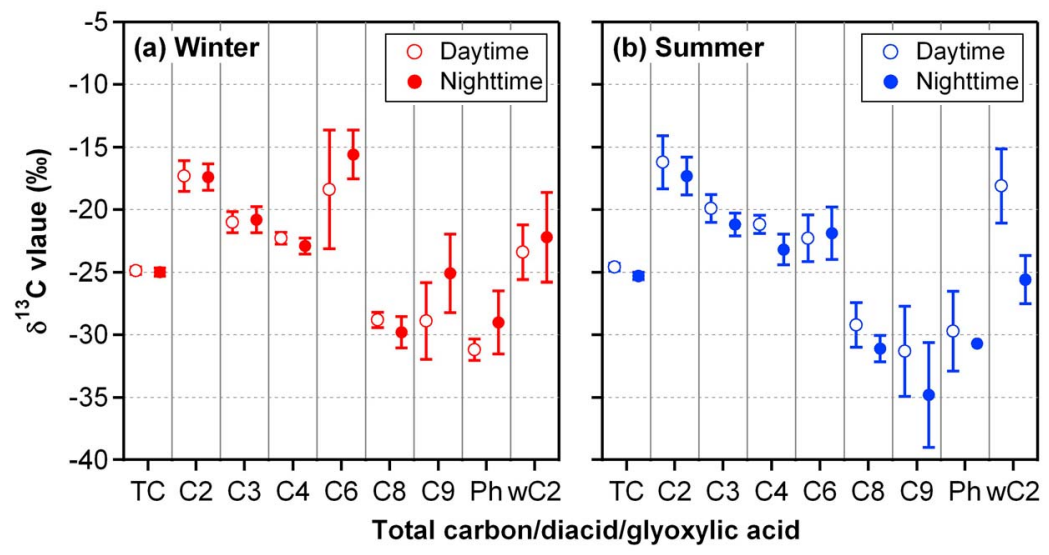

Figure 2. Average stable carbon isotopic ratios of total carbon (TC), dicarboxylic acids $\left(\mathrm{C}_{2}-\mathrm{C}_{9}\right)$ and glyoxylic acid $\left(\omega \mathrm{C}_{2}\right)$ in the tropical Indian aerosols $\left(\mathrm{PM}_{10}\right)$ from Chennai, India for day- and nighttime in (a) winter (January 23 to February 6) and (b) summer (May 22-31) 2007. Whiskers indicate the $95 \%$ confidence interval.

ryegrass $\left(\mathrm{C}_{3}\right.$ plant), but lower than those of the particles emitted from burning of $\mathrm{C}_{4}$ plants, as well as unburned dung collected from beef steer fed on maize $\left(\mathrm{C}_{4}\right.$ plant) (Figure $3 b$ ). It is of interest to note that the Chennai aerosols are slightly enriched with ${ }^{13} \mathrm{C}$ than the particles emitted from diesel $(-26.5 \%)$ and fuel oil $(-26.0 \%)$ combustion. Their $\delta^{13} \mathrm{C}$ values are close to those of the particles emitted from regular- $(-24.5 \%)$ and unleaded-petrol $(-24.2 \%)$ (Figure $3 b)$. In fact, the majority of energy source in transport sector comes from diesel fuels, whose emission factor of $\mathrm{PM}_{2.5}$ is higher $\left(4.37 \mathrm{~g} \mathrm{~kg}^{-1}\right)$ than petrol $\left(1.03 \mathrm{~g} \mathrm{~kg}^{-1}\right)$ in South and Southeast Asia, particularly in India [Reddy and Venkataraman, 2002]. Based on these comparisons and air mass trajectories that arrived in Chennai during the campaigns, we infer that the biofuel (cow-dung) and biomass $\left(\mathrm{C}_{3}\right.$ Plants) burnings are the major sources of carbonaceous aerosols in South and Southeast Asia.

\section{3. $\delta^{13} \mathrm{C}$ of Cow-Dung and Comparison to Chennai Aerosols}

[20] As noted before, the use of biofuel, particularly dung cake, for cooking is very common in South and Southeast Asia, which may add a significant amount of carbonaceous aerosols to the atmosphere. The emission factor of $\mathrm{PM}_{2.5}$ from the burning of cow-dung cake in India was reported to be $5.4 \mathrm{~g} \mathrm{~kg}^{-1}$, in which TC accounts for $47 \%$ of the smoke [Stone et al., 2010]. In order to evaluate the importance of cow-dung, we analyzed three cow-dung samples collected from Chennai for TC and $\delta^{13} \mathrm{C}$. Their TC contents ranged from $31.7 \%$ to $39.7 \%$ (ave. $34.4 \%$ ) and their $\delta^{13} \mathrm{C}$ values ranged from $-22.4 \%$ to $-26.9 \%$ (ave. $-24.7 \%$ ). The dung sample collected in barnyard showed lower $\delta^{13} \mathrm{C}(-26.9 \%)$ than that collected on the roadside $(-22.4 \%)$, whereas dung cake from commercial vendor showed a medium $(-24.9 \%)$. This difference is likely caused by the difference in type of samples rather than the variation of locations, although the sample numbers are limited. The higher $\delta^{13} \mathrm{C}$ value in the dung sample collected on the roadside seems to be reasonable because it should be enriched in ${ }^{13} \mathrm{C}$ during microbial degradation of organic materials [Thullner et al., 2008].

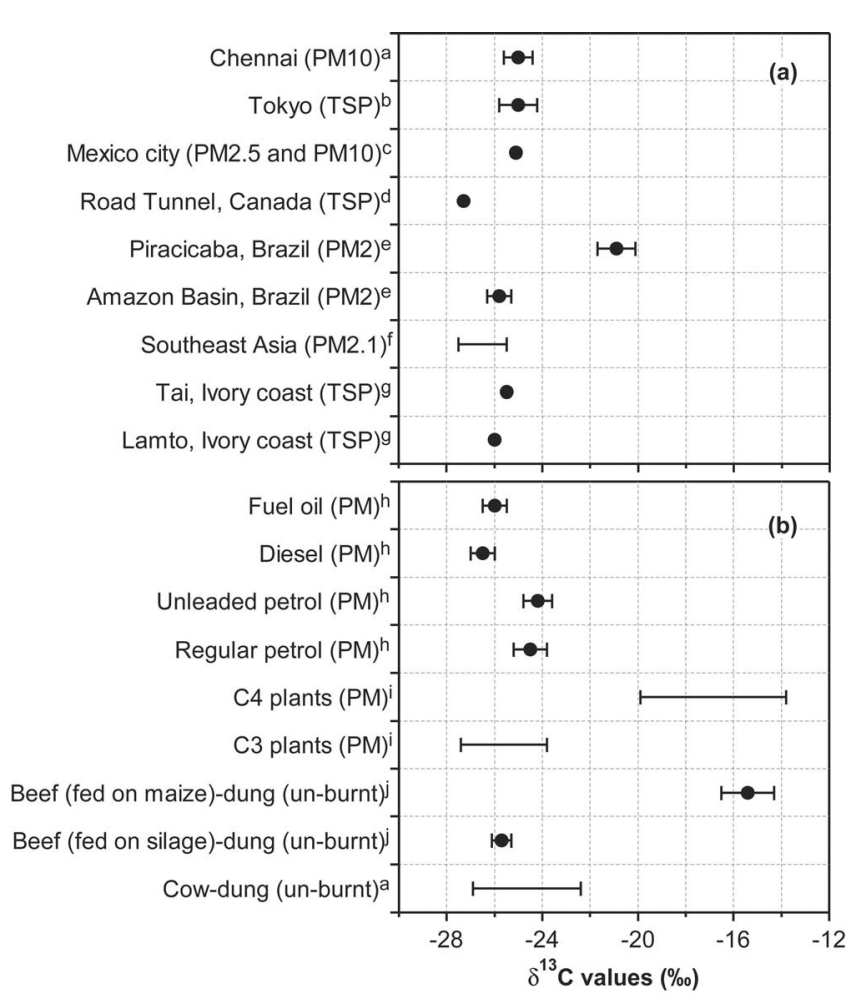

Figure 3. Range or mean (including standard deviation) of stable carbon isotope ratios $\left(\delta^{13} \mathrm{C}\right)$ in (a) Chennai aerosols $(n=49)$ together with ambient aerosols from different locale influenced by different types of sources and (b) particles emitted from point sources, and unburned beef-dung, together with cow-dung samples collected from Chennai, India. Footnotes are as follows: This study (footnote a); K. Kawamura, unpublished data, 2003 (footnote b); LópezVeneroni [2009] (footnote c); Huang et al. [2006] (footnote d); Martinelli et al. [2002] (footnote e); Narukawa et al. [1999] (footnote f); Cachier et al. [1985] (footnote g); Widory et al. [2004] (footnote h); Turekian et al. [1998] (footnote i); Bol et al. [2000] (footnote j). 


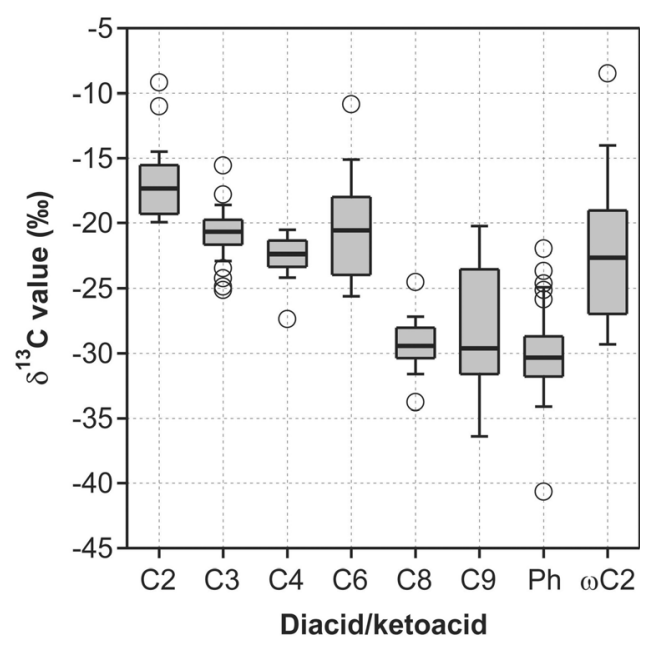

Figure 4. Box-and-whisker plot of stable carbon isotopic ratios $\left(\delta^{13} \mathrm{C}\right)$ of diacids $\left(\mathrm{C}_{2}-\mathrm{C}_{9}\right)$ and glyoxylic acid $\left(\omega \mathrm{C}_{2}\right)$ in the tropical Indian aerosols $\left(\mathrm{PM}_{10}\right)$ collected on day- and nighttime bases in winter (January 23 to February 6 ) and summer (May 22-31) 2007 from Chennai, India. Lower and upper ends of box and the lower and upper bars show the quartiles at $25 \%$ and $75 \%$ and the whiskers at $10 \%$ and $90 \%$, respectively. The cross bar in the box shows the median and open circles show the outliers.

[21] The range of $\delta^{13} \mathrm{C}$ values in Chennai aerosols (-25.9\%o to $-23.9 \%$; ave. $-25.0 \%$ ) are within the range of cow-dung samples $(-22.4 \%$ to $-26.9 \%$; ave. $-24.7 \%$ ). The average values are very similar. In addition, $\delta^{13} \mathrm{C}$ values in Chennai aerosols are comparable to those $(-25.7 \pm 0.4 \%$ ) reported for dung collected from beef steer fed on perennial ryegrass $\left(C_{3}\right.$ plant) [Bol et al., 2000]. In fact, the enrichment of ${ }^{13} \mathrm{C}$ in the particles emitted from burning of $\mathrm{C}_{3}$ plants is minimal (range $-0.6 \%$ to $1.8 \%$; ave. $0.5 \%$ ) [Turekian et al., 1998] and hence, we presume that the enrichment of ${ }^{13} \mathrm{C}$ during cowdung combustion process is also negligible. Thus, these isotopic signatures and comparisons indicate that biofuel (cow-dung) combustion is a major source of carbonaceous aerosols, in addition to biomass burning, in South and Southeast Asia, although we cannot preclude the contribution from marine sources.

\section{4. $\delta^{13} \mathrm{C}$ of Dicarboxylic Acids and Glyoxylic Acid - Seasonal Changes}

[22] The statistical distributions of $\delta^{13} \mathrm{C}$ values of seven diacids $\left(\mathrm{C}_{2}-\mathrm{C}_{9}\right)$ and glyoxylic acid $\left(\omega \mathrm{C}_{2}\right)$ in the tropical Indian aerosols $\left(\mathrm{PM}_{10}\right)(\mathrm{n}=49)$ are shown by box-andwhisker plot in Figure 4. On average, oxalic $\left(\mathrm{C}_{2}\right)$ acid $(-17.1 \pm 2.5 \% ; n=49)$ was found to be most enriched with ${ }^{13} \mathrm{C}$ followed by adipic $\left(\mathrm{C}_{6}\right)(-20.6 \pm 4.1 \%)$ and malonic $\left(\mathrm{C}_{3}\right)$ acids $\left(-20.8 \pm 1.8 \%\right.$ ) (Figure 4). The $\delta^{13} \mathrm{C}$ values of three dominant diacids $\left(\mathrm{C}_{2}, \mathrm{C}_{3}\right.$ and $\left.\mathrm{C}_{4}\right)$ ranged from $-9.2 \%$ to $-27.4 \%$ with an average of $-17.1 \%$, $-20.8 \%$ o and $-22.5 \%$ o $(n=49)$, respectively. They did not show any significant difference between winter and summer (Table 1). Suberic $\left(\mathrm{C}_{8}\right)$ and phthalic $(\mathrm{Ph})$ acids also did not show a significant change in $\delta^{13} \mathrm{C}$ between winter and summer (Table 1), but they are more depleted with ${ }^{13} \mathrm{C}(-29.4 \pm 1.8 \%$ o and $-30.1 \pm 3.5 \%$, respectively; $n=49$ ) compared to $\mathrm{C}_{2}-\mathrm{C}_{4}$ diacids (Figure 4). In contrast, the average $\delta^{13} \mathrm{C}$ values of $\mathrm{C}_{6}$ and azelaic $\left(\mathrm{C}_{9}\right)$ acids decreased from winter to summer by about $5 \%$, although the data sets are limited (Table 1 ). $\omega \mathrm{C}_{2}$ showed similar $\delta^{13} \mathrm{C}$ values in winter and summer (Table 1) with a higher average of $-22.4 \pm 5.5 \%$ o $(n=49)$.

[23] $\mathrm{C}_{6}$ diacid is produced in the atmosphere by oxidations of cyclic olefins emitted from fossil fuel combustion [Kawamura et al., 1996]. It can also be produced by photochemical oxidation of biogenic emissions (e.g., oleic acid) and/or higher homologues of diacids [Matsunaga et al., 1999]. $\mathrm{C}_{9}$ diacid is mainly produced by atmospheric oxidation of unsaturated fatty acids emitted from biogenic (marine and terrestrial plants) sources and/or biomass burning [Kawamura et al., 1996]. In fact, the emission of VOCs from tropical plants in India is higher in summer than winter [Padhy and Varshney, 2005]. Conversely, Pavuluri et al. [2010] found higher concentrations of longer-chain $\left(\mathrm{C}_{5^{-}}\right.$ $\mathrm{C}_{12}$ ) diacids; for example, $\mathrm{C}_{6}$ and $\mathrm{C}_{9}$ diacids (ave. $9.4 \mathrm{ng} \mathrm{m}^{-3}$ and $32 \mathrm{ng} \mathrm{m}^{-3}$, respectively) in summer than in winter (ave. $5.7 \mathrm{ng} \mathrm{m}^{-3}$ and $13 \mathrm{ng} \mathrm{m}^{-3}$, respectively); the latter diacid is considered to be immediate secondary product of biogenic organic compounds (i.e., unsaturated fatty acids) [Kawamura et al., 1996; Kawamura et al., 2001] in the tropical Indian aerosols.

[24] Hence, the lower $\delta^{13} \mathrm{C}$ values of $\mathrm{C}_{9}$ diacid (and $\mathrm{C}_{6}$ diacid) in summer are seemingly reasonable because $\delta^{13} \mathrm{C}$ values of unsaturated fatty acids emitted from higher plants should be depleted in ${ }^{13} \mathrm{C}$ as evidenced by $\delta^{13} \mathrm{C}$ values (range, $-38.5 \%$ to $-32.4 \%$ ) of fatty acids from unburned $\mathrm{C}_{3}$ vegetation [Ballentine et al., 1998]. On the other hand, the high $\delta^{13} \mathrm{C}$ values of $\mathrm{C}_{9}$ diacid (and $\mathrm{C}_{6}$ diacid) in winter samples may be associated with biomass burning because the air masses that arrived in Chennai originated from ME/IN/SEA (Figure 1) where biofuel/biomass burning emissions are highly significant [Streets et al., 2003] and because the combustion-derived fatty acids exhibit an enrichment of $2 \%$ to $7 \%$ [Ballentine et al., 1998]. The large enrichment of ${ }^{13} \mathrm{C}$ in $\mathrm{C}_{6}$ diacid in winter samples (Figure 2a) is apparent, possibly due to the contribution of fossil fuel combustion and burnings of $\mathrm{C}_{4}$ plants in South and Southeast Asia. In fact, biomass burning starts in January and the atmospheric concentrations of its emissions (e.g., $\mathrm{CO}$ ) reach to medium level in February and a peak in March in this region [Streets et al., 2003]. Thus, the seasonal changes in $\delta^{13} \mathrm{C}$ of $\mathrm{C}_{9}$ diacid indicate that the contributions of organics from tropical plant emissions are significant, particularly in summer, in South and Southeast Asia.

\subsection{Diurnal Shifts in $\delta^{13} \mathrm{C}$ of Diacids and Glyoxylic Acid}

[25] Average $\delta^{13} \mathrm{C}$ values of diacids and $\omega \mathrm{C}_{2}$ varied by $\geq 0.5 \%$ between day- and nighttime in both winter and summer, except for $\mathrm{C}_{2}$ and $\mathrm{C}_{3}$ diacids in winter (Figure 2). Although the differences are not significant, the observed diurnal shifts are interesting as they showed opposite trends between winter and summer: high $\delta^{13} \mathrm{C}$ values in nighttime in winter and daytime in summer (Figure 2). In addition, short-chain $\left(\mathrm{C}_{2}-\mathrm{C}_{4}\right)$ diacids did not show any diurnal variation in winter (Figure 2a) but showed a little variation in summer (Figure $2 b$ ). These diurnal shifts might be driven by 


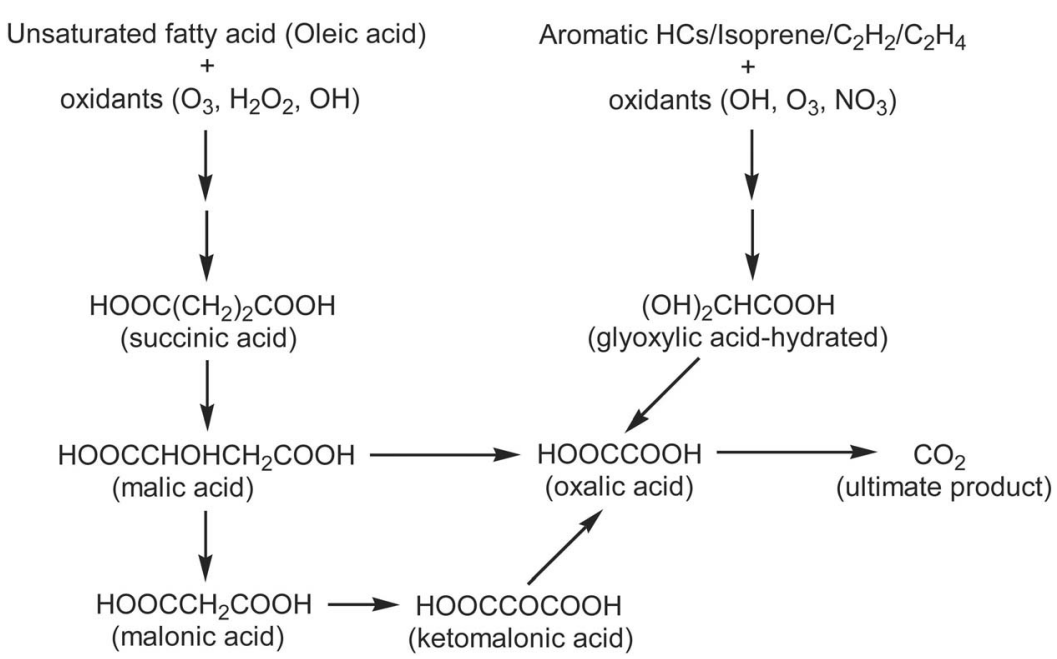

Figure 5. Possible photochemical production and degradation pathways of oxalic $\left(\mathrm{C}_{2}\right)$, malonic $\left(\mathrm{C}_{3}\right)$, succinic $\left(\mathrm{C}_{4}\right)$ and glyoxylic $\left(\omega \mathrm{C}_{2}\right)$ acids in the atmosphere [Kawamura et al., 2001; Kawamura et al., 1996; Lim et al., 2005; Warneck, 2003].

different origin and photochemical processing of organic aerosols and by land/sea breeze circulation that cause the aloft flow of the marine air masses onshore in daytime and the inland air masses offshore in nighttime [ $L u$ and Turco, 1994; Miller et al., 2003].

[26] In winter, the origin of Chennai aerosols should be similar: biofuel/biomass burning, in both day- and nighttime as the air masses originated from continental region (Figure 1) and hence diurnal variations in $\delta^{13} \mathrm{C}$ could be driven by land/ sea breeze. The onset of the sea breeze in daytime develops the thermal internal boundary layer (TIBL) extending up to 50-100 $\mathrm{m}$ above ground level under planetary boundary layer (PBL) at the coast in Chennai region [Srinivas et al., 2007] that restricts the vertical distribution of pollutants. In contrast, the TIBL disappears and the PBL moves down after the onset of land breeze in nighttime. In addition, the oxidant concentration may stay high under nighttime smog condition at surface level [Miller et al., 2003]. Hence the contribution of fresh aerosols (long-chain diacids and $\omega \mathrm{C}_{2}$ ) produced by in situ photochemical processing of precursors may be significant in daytime whereas in nighttime the contribution of aged aerosols transported from distant sources as well as further processing of aerosols under high oxidant conditions may be significant, leading to ${ }^{13} \mathrm{C}$ enrichment in nighttime.

[27] The enrichment of ${ }^{13} \mathrm{C}$ in all the diacid species, except for $\mathrm{C}_{6}$, and $\omega \mathrm{C}_{2}$ in summer daytime (Figure $2 \mathrm{~b}$ ) could be due to significant contributions of aged marine aerosols as the air masses that arrived in Chennai originated from the Arabian Sea and/or Indian Ocean (Figure 1). In addition, sea breeze brings a lot of marine air masses that mixed with continental air masses transported during previous night, which were subjected to further oxidation process during nighttime, leading to ${ }^{13} \mathrm{C}$ enrichment. On the other hand, the depletion of ${ }^{13} \mathrm{C}$ in those species in summer nighttime might be caused by significant contributions from higher plant emissions, which should have smaller $\delta^{13} \mathrm{C}$ values than those of biofuel/ biomass burning emissions and/or marine aerosols, because land breeze brings lots of inland air masses enriched with fresh aerosols produced during the daytime. As discussed earlier, the emission of VOCs from tropical plants [Padhy and Varshney 2005] and their subsequent contribution to aerosol budget [Pavuluri et al., 2010] is higher in summer than winter in India.

\subsection{Enrichment of ${ }^{13} \mathrm{C}$ in Oxalic Acid: Implication for Photochemical Processing}

[28] Unidirectional chemical reactions generally show an enrichment of ${ }^{12} \mathrm{C}$ in reaction products with the remaining reactants being isotopically heavier [Hoefs, 1997]. On the other hand, the occurrence of chemical processing within the aerosol causes the enrichment of ${ }^{13} \mathrm{C}$ in the substrate (product retained in particle phase), if some of the reaction products are volatile [Turekian et al., 2003]. Laboratory experiments and ambient measurements have found that the remaining aliphatic/aromatic hydrocarbons including isoprene become more enriched in ${ }^{13} \mathrm{C}$ after photochemical reactions with $\mathrm{OH}$ radicals [Rudolph et al., 2000, 2002, 2003]. In addition, phase partitioning (e.g., gas to particle) of a compound can result in isotopic fractionation [Hoefs, 1997].

[29] The possible photochemical production and degradation pathways of $\mathrm{C}_{2}, \mathrm{C}_{3}, \mathrm{C}_{4}$ and $\omega \mathrm{C}_{2}$ acids are depicted in Figure 5. Kawamura and Ikushima, [1993] proposed that $C_{2}$ diacid may be produced in the atmosphere by photochemical oxidations of $\mathrm{C}_{3}$ diacid that can be produced from $\mathrm{C}_{4}$ diacid. Glyoxylic acid $\left(\omega \mathrm{C}_{2}\right)$ is an intermediate compound in the formation pathway of $\mathrm{C}_{2}$ diacid by photooxidation of isoprene [Lim et al., 2005] and other precursor compounds such as aromatic hydrocarbons [Kawamura et al., 1996] and ethyne and/or ethene [Warneck, 2003]. Further, $\mathrm{C}_{2}$ diacid can undergo a decarboxylation reaction by photochemical oxidation in the presence of iron species [Zuo and Hoigne, 1994]. Hence, $C_{2}$ diacid that remains in particle phase should be enriched with ${ }^{13} \mathrm{C}$ when the atmospheric aerosols are subjected to significant photochemical processing (e. g., decarboxylation reaction) during long-range transport. In the oxidative degradation of $\mathrm{C}_{4}$ and $\mathrm{C}_{3}$ diacid, similar enrichment of ${ }^{13} \mathrm{C}$ may occur in the remaining diacid. 


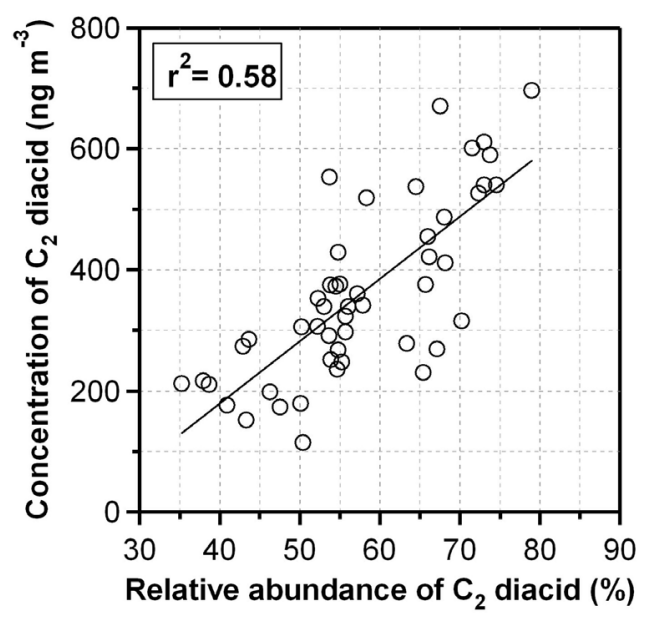

Figure 6. Plot showing the linear relation between concentrations of oxalic $\left(\mathrm{C}_{2}\right)$ acid and its relative abundance to total diacids in the tropical Indian aerosols $\left(\mathrm{PM}_{10}\right)$ collected from Chennai, India in winter (January 23 to February 6) and summer (May 22-31) 2007. Data from Pavuluri et al. [2010].

[30] As expected, we found an increasing trend in $\delta^{13} \mathrm{C}$ values from $\mathrm{C}_{4}$ to $\mathrm{C}_{2}$ diacids in Chennai aerosols, that is, $\mathrm{C}_{2}$ diacid was more enriched in ${ }^{13} \mathrm{C}$ than $\mathrm{C}_{3}$ and $\mathrm{C}_{4}$ diacids (Table 1 and Figure 4). $\omega \mathrm{C}_{2}$ also showed fairly higher $\delta^{13} \mathrm{C}$ values, but lower than that of $\mathrm{C}_{2}$ diacid (Figure 4 ). Further, the range $\left(-9.2 \%\right.$ to $-27.4 \%$ ) and average $\delta^{13} \mathrm{C}$ values of $\mathrm{C}_{2}, \mathrm{C}_{3}$ and $\mathrm{C}_{4}$ diacids $(-17.1 \%,-20.8 \%$ and $-22.5 \%$, respectively) in Chennai aerosols are comparable to those reported for remote marine aerosols (range: $-9.1 \%$ to $-27.1 \%$; ave. $-16.8 \%,-21.5 \%$ and $-20.3 \%$, respectively) [Wang and Kawamura, 2006] and Sapporo aerosols (range $-14.0 \%$ to $-25.3 \%$; ave $-18.8 \%$ o, $-21.7 \%$ and $-22.7 \%$, respectively) [Aggarwal and Kawamura, 2008], which were considered as photochemically aged during long-range atmospheric transport. Thus, the higher $\delta^{13} \mathrm{C}$ in smaller diacids, in particular the large enrichment of ${ }^{13} \mathrm{C}$ in $\mathrm{C}_{2}$ diacid, found in Chennai aerosols (Figure 4) and their comparability to aged aerosols indicate that the Chennai aerosols have significantly been subjected to photochemical processing in the tropical atmosphere during long-range transport from source regions in South and Southeast Asia.

\subsection{Relations of $\delta^{13} \mathrm{C}$ of $\mathrm{C}_{2}-\mathrm{C}_{4}$ Diacids and $\omega \mathrm{C}_{2}$ With Proxies for Photochemical Processing}

[31] As photochemical breakdown of longer-chain diacids can produce the shorter-chain diacids in the atmosphere, the relative abundance $\left(\mathrm{C}_{2} \%\right)$ of $\mathrm{C}_{2}$ diacid, an end product of the chain reactions, has been proposed as a measure of photochemical processing [Kawamura and Sakaguchi, 1999]. $\delta^{13} \mathrm{C}$ values of $\mathrm{C}_{2}-\mathrm{C}_{4}$ and $\omega \mathrm{C}_{2}$ acids and $\mathrm{C}_{2} \%$ in Chennai aerosols showed weak mixed (positive and negative) correlations ( $\mathrm{r}=$ $(-) 0.67$ to 0.52$)$. Further, the positive correlations found in Chennai aerosols were much weaker than those $\left(\mathrm{r}^{2}=0.58\right.$, 0.86 and 0.68 , respectively) reported in remote marine aerosols [Wang and Kawamura, 2006]. But $\delta^{13} \mathrm{C}$ of $\mathrm{C}_{2}$ and $\mathrm{C}_{3}$ diacids in Chennai aerosols (Table 1) are comparable to those $(-16.8 \pm 0.8 \%$ and $-21.5 \pm 0.6 \%$, respectively) reported in remote marine aerosols [Wang and Kawamura, 2006]. This discrepancy is probably due to differences in the extent of photochemical destruction of diacids and related compounds, which may be quite different between the remote marine and continental atmospheres; that is, differences in mixing processes, removal of oxygenated species and additional input of their precursors along the transport pathway.

[32] In fact, concentrations of $\mathrm{C}_{2}$ are positively correlated with $\mathrm{C}_{2} \%$ in Chennai aerosols (see Figure 6). This positive correlation indicates that photochemical production of $\mathrm{C}_{2}$ was more pronounced than its photochemical destruction in the Chennai aerosols, being opposite to that reported in remote marine aerosols [Wang and Kawamura, 2006]. This is reasonable because the air masses that arrived in Chennai might be mixed with fresh precursors along the transport pathway as they passed over the continents (Figure 1) where the biofuel/ biomass burning emissions are significant, whereas in the case of remote marine aerosols, the additional input of primary precursors (except marine biota emissions) may be minor. Hence, the relations between $\delta^{13} \mathrm{C}$ of diacids and $\mathrm{C}_{2} \%$ may be varied depending on the availability of primary precursors in the continental atmosphere, although the photochemical processing is significant.

[33] On the other hand, the ratio of water-soluble organic carbon (WSOC) to organic carbon (OC) has also been proposed as a measure of photochemical processing [Aggarwal and Kawamura, 2009; Yang et al., 2004] because prolonged photochemical oxidation of organics results in secondary organic aerosol (SOA) enriched with polar (watersoluble) compounds. $\delta^{13} \mathrm{C}$ of $\mathrm{C}_{2}-\mathrm{C}_{4}$ and $\omega \mathrm{C}_{2}$ acids showed a positive correlation $(\mathrm{r}=$ up to 0.44$)$ with $\mathrm{WSOC} / \mathrm{OC}$ ratio, except for three cases; $\mathrm{C}_{2}$ and $\mathrm{C}_{3}$ in summer day- and nighttime, respectively, and $\omega C_{2}$ in summer daytime. The correlation coefficients found between $\delta^{13} \mathrm{C}$ of $\mathrm{C}_{2}, \mathrm{C}_{3}$ and $\mathrm{C}_{4}$ diacids and WSOC/OC ratio in Chennai aerosols are comparable to those ( $r=0.51,0.55$ and 0.52 , respectively) reported for Sapporo aerosols, which were considered as photochemically aged during long-range atmospheric transport [Aggarwal and Kawamura, 2008].

[34] The weak negative correlations between $\delta^{13} \mathrm{C}$ values of diacids and $\mathrm{WSOC} / \mathrm{OC}$ ratios were driven by a large enrichment of ${ }^{13} \mathrm{C}$ in $\mathrm{C}_{2}$ diacid in two samples (IND176 and IND189; Table 1) and a depletion of ${ }^{13} \mathrm{C}_{\text {in }} \mathrm{C}_{3}$ diacid in one sample (IND186; Table 1), probably due to an additional input from unknown sources that could affect the $\delta^{13} \mathrm{C}$. Unfortunately, additional information such as ozone is not available to discuss further. The negative correlation between $\delta^{13} \mathrm{C}$ of $\omega \mathrm{C}_{2}$ and WSOC/OC ratio that was driven by few samples may be attributed to the differences in origin of aerosols as the air masses are mixed; marine and continental. Because the precursors of $\omega \mathrm{C}_{2}$ (Figure 5) may be emitted from marine biota, higher plants and anthropogenic sources, glyoxylic acid may give different $\delta^{13} \mathrm{C}$ values (Figure 4).

\section{Summary and Conclusions}

[35] The tropical Indian aerosols $\left(\mathrm{PM}_{10}\right)$ collected on day- and nighttime bases in winter and summer, 2007 from Chennai were studied for stable carbon isotopic ratios $\left(\delta^{13} \mathrm{C}\right)$ of TC, diacids and $\omega C_{2} . \delta^{13} \mathrm{C}$ values of TC, diacids (except $\mathrm{C}_{6}$ and $\left.\mathrm{C}_{9}\right)$ and $\omega \mathrm{C}_{2}$ did not vary from winter to summer. The $\delta^{13} \mathrm{C}$ values of TC in Chennai aerosols were similar to those of unburned cow-dung collected from Chennai as well as the dung collected from beef steer fed on silage $\left(\mathrm{C}_{3}\right.$ plant $)$. 
Furthermore, they were comparable to $\delta^{13} \mathrm{C}$ values of the particles emitted from the burning of $\mathrm{C}_{3}$ plants. These findings together with air mass trajectories infer that biofuel/ biomass burning are the major sources of aerosol carbon in South and Southeast Asia. $\mathrm{C}_{2}$ diacid showed higher $\delta^{13} \mathrm{C}$ values than other species, suggesting photochemical processing of organic aerosols. ${ }^{13} \mathrm{C}$ of all the species, except for $\mathrm{C}_{2}$ and $\mathrm{C}_{3}$ diacids in winter, showed a weak diurnal variation. $\mathrm{C}_{4}-\mathrm{C}_{2}$ diacids showed an increasing trend in $\delta^{13} \mathrm{C}$ values with a decrease in carbon numbers due to the ${ }^{13} \mathrm{C}$ enrichment of small diacids during photochemical breakdown. $\omega \mathrm{C}_{2}$ also showed fairly large $\delta^{13} \mathrm{C}$ but smaller than that of $\mathrm{C}_{2}$ diacid. In addition, the seasonal changes in $\delta^{13} \mathrm{C}$ values of $\mathrm{C}_{9}$ diacid suggest significant contributions of organic aerosols from higher plant emissions, particularly in summer. The diurnal variations in $\delta^{13} \mathrm{C}$ of the species indicate the role of land/sea breeze at the Chennai coast and also the differences in emission sources. A large enrichment of ${ }^{13} \mathrm{C}$ in $\mathrm{C}_{2}$ diacid, positive correlations between $\delta^{13} \mathrm{C}$ values of $\mathrm{C}_{2}-\mathrm{C}_{4}$ and $\omega \mathrm{C}_{2}$ acids and WSOC/OC ratios, in most of the cases, imply that the Chennai aerosols have been subjected to significant photochemical processing in the tropical atmosphere during long-range transport from source regions.

[36] Acknowledgments. This study was partly supported by a grantin-aid 19204055 from the Japan Society for the Promotion of Science (JSPS) and the Environment Research and Technology Development Fund (B-0903) of the Ministry of the Environment, Japan. We appreciate the financial support of a JSPS Fellowship to C. M. P. We also thank R. A. Damodar and $\mathrm{K}$. Jagannathan for their support in the sample collection.

\section{References}

Aggarwal, S. G., and K. Kawamura (2008), Molecular distributions and stable carbon isotopic compositions of dicarboxylic acids and related compounds in aerosols from Sapporo, Japan: Implications for photochemical aging during long-range atmospheric transport, J. Geophys. Res., 113, D14301, doi:10.1029/2007JD009365.

Aggarwal, S. G., and K. Kawamura (2009), Carbonaceous and inorganic composition in long-range transported aerosols over northern Japan: Implications for aging of water-soluble organic fraction, Atmos. Environ., 43, 2532-2540, doi:10.1016/j.atmosenv.2009.02.032.

Ballentine, D., S. A. Macko, and V. C. Turekian (1998), Variability of stable carbon isotopic compositions in individual fatty acids from combustion of $\mathrm{C}_{4}$ and $\mathrm{C}_{3}$ plants: Implications for biomass burning, Chem. Geol., 152, 151-161, doi:10.1016/S0009-2541(98)00103-X.

Baltensperger, U., et al. (2008), Combined determination of the chemical composition and of health effects of secondary organic aerosols: The POYSOA project, J. Aerosol Med. Pulm. Drug Delivery, 21(1), 145-154, doi:10.1089/jamp.2007.0655.

Bol, R., W. Amelung, C. Friedrich, and N. Ostle (2000), Tracing dungderived carbon in temperature grassland using ${ }^{13} \mathrm{C}$ natural abundance measurements, Soil Biol. Biochem., 32, 1337-1343, doi:10.1016/ S0038-0717(00)00022-5.

Cachier, H., P. Buat-Menard, M. Fontugne, and J. Rancher (1985), Source terms and source strengths of the carbonaceous aerosol in the tropics, J. Atmos. Chem., 3, 469-489, doi:10.1007/BF00053872.

Chesselet, R., M. Fontugne, P. Buat-Ménard, U. Ezat, and C. E. Lambert (1981), The origin of particulate organic carbon in the atmosphere as indicated by its stable carbon isotopic composition, Geophys. Res. Lett., 8(4), 345-348, doi:10.1029/GL008i004p00345.

Fang, J., K. Kawamura, and K. Matsumoto (2002), Carbon isotopic composition of fatty acids in the marine aerosols from the western North Pacific: Implication for the source and atmospheric transport, Environ. Sci. Technol., 36, 2598-2604, doi:10.1021/es015863m.

Gustafsson, Ö., M. Krusa, Z. Zencak, R. J. Sheesley, L. Granat, E. Engstöm, P. S. Praveen, P. S. P. Rao, C. Leck, and H. Rodhe (2009), Brown clouds over South Asia: Biomass or fossil fuel combustion?, Science, 323, 495-498, doi:10.1126/science.1164857.

Hoefs, J. (1997), Stable Isotope Geochemistry, Springer, New York.
Huang, L., J. R. Brook, W. Zhang, S. M. Li, L. Graham, D. Ernst, A. Chivulescu, and G. Lu (2006), Stable isotope measurements of carbon fractions $(\mathrm{OC} / \mathrm{EC})$ in airborne particulate: A new dimension for source characterization and apportionment, Atmos. Environ., 40, 2690-2705, doi:10.1016/j.atmosenv.2005.11.062.

Kawamura, K. (1993), Identification of $\mathrm{C}_{2}-\mathrm{C}_{10} \omega$-oxocarboxylic acids, pyruvic acid, and $\mathrm{C}_{2}-\mathrm{C}_{3} \alpha$-dicarbonyls in wet precipitation and aerosol samples by capillary GC and GC-MS, Anal. Chem., 65, 3505-3511, doi:10.1021/ac00071a030.

Kawamura, K., and K. Ikushima (1993), Seasonal changes in the distribution of dicarboxylic acids in the urban atmosphere, Environ. Sci. Technol., 27, 2227-2235, doi:10.1021/es00047a033.

Kawamura, K., and I. R. Kaplan (1987), Motor exhaust emissions as a primary source for dicarboxylic acids in Los Angeles ambient air, Environ. Sci. Technol., 21, 105-110, doi:10.1021/es00155a014.

Kawamura, K., and F. Sakaguchi (1999), Molecular distributions of watersoluble dicarboxylic acids in marine aerosols over the Pacific Ocean including tropics, J. Geophys. Res., 104(D3), 3501-3509, doi:10.1029/ 1998JD100041.

Kawamura, K., and K. Usukura (1993), Distributions of low molecular weight dicarboxylic acids in the North Pacific aerosol samples, J. Oceanogr., 49, 271-283, doi:10.1007/BF02269565.

Kawamura, K., and T. Watanabe (2004), Determination of stable carbon isotopic compositions of low molecular weight dicarboxylic acids and ketocarboxylic acids in atmospheric aerosol and snow samples, Anal. Chem., 76, 5762-5768, doi:10.1021/ac049491m.

Kawamura, K., and O. Yasui (2005), Diurnal changes in the distribution of dicarboxylic acids, ketocarboxylic acids and dicarbonyls in the urban Tokyo atmosphere, Atmos. Environ., 39, 1945-1960, doi:10.1016/j. atmosenv.2004.12.014.

Kawamura, K., H. Kasukabe, and L. A. Barrie (1996), Source and reaction pathways of dicarboxylic acids and dicarbonyls in Arctic aerosols: One year of observations, Atmos. Environ., 30, 1709-1722, doi:10.1016/ 1352-2310(95)00395-9.

Kawamura, K., K. Yokoyama, Y. Fujii, and O. Watanabe (2001), A Greenland ice core record of low molecular weight dicarboxylic acids, ketocarboxylic acids, and $\alpha$-dicarbonyls: A trend from Little Ice Age to the present (1540 to 1989 A.D.), J. Geophys. Res., 106(D1), 1331-1345, doi:10.1029/2000JD900465.

Kawamura, K., Y. Imai, and L. A. Barrie (2005), Photochemical production and loss of organic acids in high Arctic aerosols during long-range transport and polar sunrise depletion events, Atmos. Environ., 39, 599-614, doi:10.1016/j.atmosenv.2004.10.020.

Kundu, S., K. Kawamura, T. W. Andreae, A. Hoffer, and M. O. Andreae (2010), Molecular distributions of dicarboxylic acids, ketocarboxylic acids and $\alpha$-dicarbonyls in biomass burning aerosols: Implications for photochemical production and degradation in smoke layers, Atmos. Chem. Phys., 10, 2209-2225, doi:10.5194/acp-10-2209-2010.

Lelieveld, J., et al. (2001), The Indian Ocean experiment: Widespread air pollution from South and Southeast Asia, Science, 291, 1031-1036, doi:10.1126/science.1057103.

Lim, H.-J., A. G. Carlton, and B. J. Turpin (2005), Isoprene forms secondary organic aerosol through cloud processing: Model simulations, Environ. Sci. Technol., 39, 4441-4446, doi:10.1021/es048039h.

López-Veneroni, D. (2009), The stable carbon isotope composition of $\mathrm{PM}_{2.5}$ and $\mathrm{PM}_{10}$ in Mexico City Metropolitan area air, Atmos. Environ., 43, 4491-4502, doi:10.1016/j.atmosenv.2009.06.036.

Lu, R., and R. P. Turco (1994), Air pollutant transport in a coastal environment. Part I: Two-dimensional simulations of sea-breeze and mountain effects, J. Atmos. Sci., 51(15), 2285-2308, doi:10.1175/ 1520-0469(1994)051<2285:APTIAC >2.0.CO;2.

Maria, S. F., L. M. Russel, M. K. Gilles, and S. C. B. Myneni (2004), Organic aerosol growth mechanisms and their climate-forcing implications, Science, 306(5703), 1921-1924, doi:10.1126/science.1103491.

Martinelli, L. A., P. B. Camargo, L. B. L. S. Lara, R. L. Victoria, and P. Artaxo (2002), Stable carbon and nitrogen isotopic composition of bulk aerosol particles in a C4 plant landscape of southeast Brazil, Atmos. Environ., 36, 2427-2432, doi:10.1016/S1352-2310(01)00454-X.

Matsunaga, S., K. Kawamura, T. Nakatsuka, and N. Ohkouchi (1999), Preliminary study on laboratory photochemical formation of low molecular weight dicarboxylic acids from unsaturated fatty acid (oleic acid), Res. Org. Geochem., 14, 19-25.

Miller, S. T. K., B. D. Keim, R. W. Talbot, and H. Mao (2003), Sea breeze: Structure, forecasting, and impacts, Rev. Geophys., 41(3), 1011, doi:10.1029/2003RG000124.

Narukawa, M., K. Kawamura, N. Takeuchi, and T. Nakajima (1999), Distributions of dicarboxylic acids and carbon isotopic compositions in aerosols from 1997 Indonesian forest fires, Geophys. Res. Lett., 26(20), 3101-3104, doi:10.1029/1999GL010810. 
Narukawa, M., K. Kawamura, S.-M. Li, and J. W. Bottenheim (2008), Stable carbon isotopic ratios and ionic composition of the high-Arctic aerosols: An increase in $\delta^{13} \mathrm{C}$ values from winter to spring, J. Geophys. Res., 113, D02312, doi:10.1029/2007JD008755.

Novakov, T., M. O. Andreae, R. Gabriel, T. W. Kirchstetter, O. L. MayolBracero, and V. Ramanathan (2000), Origin of carbonaceous aerosols over the tropical Indian Ocean: Biomass burning or fossil fuels?, Geophys. Res. Lett., 27(24), 4061-4064, doi:10.1029/2000GL011759.

Padhy, P. K., and C. K. Varshney (2005), Emission of volatile organic compounds (VOC) from tropical plant species in India, Chemosphere, 59, 1643-1653, doi:10.1016/j.chemosphere.2005.01.046.

Pavuluri, C. M., K. Kawamura, and T. Swaminathan (2010), Water-soluble organic carbon, dicarboxylic acids, ketoacids and $\alpha$-dicarbonyls in the tropical Indian aerosols, J. Geophys. Res., 115, D11302, doi:10.1029/ 2009JD012661.

Pavuluri, C. M., K. Kawamura, S. G. Aggarwal, and T. Swaminathan (2011), Characteristics, seasonality, and sources of carbonaceous and ionic components in the tropical aerosols from Indian region, Atmos. Chem. Phys., 11, 8215-8230, doi:10.5194/acp-11-8215-2011.

Ramanathan, V., P. J. Crutzen, J. T. Kiehl, and D. Rosenfeld (2001), Aerosols, climate, and the hydrological cycle, Science, 294, 2119-2124, doi:10.1126/science. 1064034

Reddy, M. S., and C. Venkataraman (2002), Inventory of aerosol and sulphur dioxide emissions from India: I. Fossil fuel combustion, Atmos. Environ., 36, 677-697, doi:10.1016/S1352-2310(01)00463-0.

Rogge, W. F., L. M. Hildemann, M. A. Mazurek, G. R. Cass, and B. R. T. Simoneit (1991), Sources of fine organic aerosol. part I: Charbroilers and meat cooking operations, Environ. Sci. Technol., 25(6), 1112-1125, doi:10.1021/es00018a015.

Rudolph, J., E. Czuba, and L. Huang (2000), The stable carbon isotope fractionation for reactions of selected hydrocarbons with $\mathrm{OH}$-radicals and its relevance for atmospheric chemistry, J. Geophys. Res., 105(D24), 29,329-29,346, doi:10.1029/2000JD900447.

Rudolph, J., E. Czuba, A. L. Norman, L. Huang, and D. Ernst (2002), Stable carbon isotope composition of nonmethane hydrocarbons in emissions from transportation related sources and atmospheric observations in an urban atmosphere, Atmos. Environ., 36, 1173-1181, doi:10.1016/ S1352-2310(01)00537-4.

Rudolph, J., R. S. Anderson, K. V. Czapiewski, E. Czuba, D. Ernst, T. Gillespie, L. Huang, C. Rigby, and A. E. Thomson (2003), The stable carbon isotope ratio of biogenic emissions of isoprene and the potential use of stable isotope ratio measurements to study photochemical processing of isoprene in the atmosphere, J. Atmos. Chem., 44, 39-55, doi:10.1023/A:1022116304550.

Saito, T., U. Tsunogai, K. Kawamura, T. Nakatsuka, and N. Yoshida (2002), Stable carbon isotopic compositions of light hydrocarbons over the western North Pacific and implication for their photochemical ages, J. Geophys. Res., 107(D4), 4040, doi:10.1029/2000JD000127.

Satsumabayashi, H., H. Kurita, Y. Yokouchi, and H. Ueda (1990), Photochemical formation of particulate dicarboxylic acids under long-range transport in central Japan, Atmos. Environ., 24, 1443-1450.

Simoneit, B. R. T. (1997), Compound-specific carbon isotope analyses of individual long-chain alkanes and alkanoic acids in Harmattan aerosols, Atmos. Environ., 31, 2225-2223, doi:10.1016/S1352-2310(97)00055-1.

Srinivas, C. V., R. Venkatesan, K. M. Somayaji, and A. B. Singh (2006), A numerical study of sea breeze circulation observed at a tropical site Kalpakkam on the east coast of India under different synoptic flow situations, J. Earth Syst. Sci., 115(5), 557-574, doi:10.1007/BF02702909.

Srinivas, C. V., R. Venkatesan, and A. B. Singh (2007), Sensitivity of mesoscale simulations of land-sea breeze to boundary layer turbu- lence parameterization, Atmos. Environ., 41, 2534-2548, doi:10.1016/j. atmosenv.2006.11.027.

Stone, E. A., J. J. Schauer, B. B. Pradhan, P. M. Dangol, G. Habib, C. Venkataraman, and V. Ramanathan (2010), Characterization of emissions from South Asian biofuels and application to source apportionment of carbonaceous aerosol in the Himalayas, J. Geophys. Res., 115, D06301, doi:10.1029/2009JD011881.

Streets, D. G., K. F. Yarber, J.-H. Woo, and G. R. Carmichael (2003), Biomass burning in Asia: Annual and seasonal estimates and atmospheric emissions, Global Biogeochem. Cycles, 17(4), 1099, doi:10.1029/ 2003 GB002040.

Tata Energy Research Institute (1997), Tata Energy Directory and Data Yearbook 1996-1997, New Delhi.

Thullner, M., M. Kampara, H. H. Richnow, H. Harms, and L. Y. Wick (2008), Impact of bioavailability restrictions on microbially induced stable isotope fractionation. 1. Theoretical calculation, Environ. Sci. Technol., 42, 6544-6551, doi:10.1021/es702782c.

Turekian, V. C., S. A. Macko, D. Ballentine, R. J. Swap, and M. Garstang (1998), Causes of bulk carbon and nitrogen isotopic fractionations in the products of vegetation burns: Laboratory studies, Chem. Geol., 152, 181-192, doi:10.1016/S0009-2541(98)00105-3.

Turekian, V. C., S. A. Macko, and W. C. Keene (2003), Concentrations, isotopic compositions, and sources of size-resolved, particulate organic carbon and oxalate in near-surface marine air at Bermuda during spring, J. Geophys. Res., 108(D5), 4157, doi:10.1029/2002JD002053.

Venkataraman, C., G. Habib, A. Eiguren-Fernandez, A. H. Miguel, and S. K. Friedlander (2005), Residential biofuels in South Asia: Carbonaceous aerosol emissions and climate impacts, Science, 307, 1454-1456, doi: $10.1126 /$ science. 1104359 .

Wang, H., and K. Kawamura (2006), Stable carbon isotopic composition of low-molecular-weight dicarboxylic acids and ketoacids in remote marine aerosols, J. Geophys. Res., 111, D07304, doi:10.1029/2005JD006466.

Wang, Y. Q., X. Y. Zhang, R. Arimoto, J. J. Cao, and Z. X. Shen (2005), Characteristics of carbonate content and carbon and oxygen isotopic composition of northern China soil and dust aerosol and its application to tracing dust sources, Atmos. Environ., 39, 2631-2642, doi:10.1016/j. atmosenv.2005.01.015.

Warneck, P. (2003), In-cloud chemistry opens pathway to the formation of oxalic acid in the marine atmosphere, Atmos. Environ., 37, 2423-2427, doi:10.1016/S1352-2310(03)00136-5.

Widory, D., S. Roy, Y. L. Moullec, G. Goupil, A. Cocherie, and C. Guerrot (2004), The origin of atmospheric particles in Paris: A view through carbon and lead isotopes, Atmos. Environ., 38, 953-961, doi:10.1016/j. atmosenv.2003.11.001

World Bank (2000), World Development Report 1999/2000: Entering Into the 21st Century, World Bank, Washington, D. C.

Yang, H., J. Xu, W.-S. Wu, C. H. Wan, and J. Z. Yu (2004), Chemical characterization of water-soluble organic aerosols at Jeju Island collected during ACE-Asia, Environ. Chem., 1, 13-17, doi:10.1071/EN04006.

Zuo, Y. G., and J. Hoigne (1994), Photochemical decomposition of oxalic, glyoxalic and pyruvic-acid catalyzed by iron in atmospheric waters, Atmos. Environ., 28, 1231-1239, doi:10.1016/1352-2310(94)90270-4.

K. Kawamura, C. M. Pavuluri, and E. Tachibana, Institute of Low Temperature Science, Hokkaido University, N19 W08, Kita-ku, Sapporo 060-0819, Japan. (kawamura@lowtem.hokudai.ac.jp)

T. Swaminathan, Department of Chemical Engineering, Indian Institute of Technology Madras, Chennai 600036, India. 